\title{
Assessing Uptake Kinetics and Natural Depuration of Lead and Cadmium in African Catfish Juvenile
}

\author{
*BABATUNDE, BB; DIKE CS; IBEKWE CJ
}

\author{
Department of Animal and Environmental Biology, Faculty of Science, University of Port Harcourt
}

*Corresponding Author Email: bolaji.babatunde@uniport.edu.ng

\begin{abstract}
This study was carried out to assess the uptake kinetics of two heavy metals lead and cadmium in African catfish juveniles and their ability to depurate during subsequent exposure to clean water. Catfish juveniles with average weight and length of $5.3 \mathrm{~g}$ and $5.8 \mathrm{~cm}$ respectively were randomly selected and acclimatized for two weeks. A 24 hour range finding test was carried out. In the definite test, the fish were stocked in 24 tanks containing 5litres of water with lead and cadmium treatment separately labeled according to predetermined concentrations $5,10,15,20,25 \mathrm{mg}$ for lead and cadmium with 4 fish in each treatment. The water and fish were analyzed for the metals after 5 days to show percentage uptake of the metals from the water. The fish were transferred back into clean water to access the rate of depuration and water was changed continuously. After 4 days the fish were analyzed again to see if they were purged of the heavy metals. Based on these findings catfish have shown to be good accumulators of heavy metals but can be depurated if allowed to swim in clean water. Uptake percentage after the period of exposure to $5 \mathrm{mg}, 10 \mathrm{mg}, 15 \mathrm{mg}, 20 \mathrm{mg}$, $25 \mathrm{mg}$ concentrations were $18.68,10.17,5.95,1.41,8.26$ for cadmium and 20.47, 10.17, 8.76, 9.92, 10.08 for lead; Percentage of metals depurated after 4 days were $40.00,80.70,90.00,77.78,45$ for cadmium and 73.045, 20.413, 41.425, $37.580,61.141$ for lead. Lead was readily taken but cadmium was readily depurated.
\end{abstract}

\section{DOI: https://dx.doi.org/10.4314/jasem.v24i2.3}

Copyright: Copyright $\left({ }_{0} 2020\right.$ Babatunde et al. This is an open access article distributed under the Creative Commons Attribution License (CCL), which permits unrestricted use, distribution, and reproduction in any medium, provided the original work is properly cited.

Dates: Received: 16 November 2019; Revised: 11 January 2020; Accepted: 22 February 2020

Keywords: Heavy metals, juvenile catfish, exposure, uptake and depuration

Heavy metals are trace components of the aquatic environment, whose level have been reported to be on the increase in recent times due to pollution from industrial wastes, changes in geochemical structure, agricultural and mining activities (Singh et al., 2007; Sprocati et al., 2006). Heavy metals unlike organic contaminants are not degraded with time, but concentration can only increase through bioaccumulation (Aksoy, 2008). The ubiquitous presence and use of heavy metals has not been without significant consequences (UNEP-CEP, 2008). Industrial and agricultural applications of heavy metals have added large amount of these metals, making the fishes unsafe for consumption (CastroGonzález and Méndez-Armenta, 2008). The concentrations of these toxic substances, however, in rivers, lakes, and oceans are very low but they can accumulate to very high concentration in fishes and other marine organisms by bioaccumulation and biomagnification mechanisms resulting to high occurrences of cardiovascular, inflammatory and associated diseases. Various disease associated with consumption of seafood has prompted investigation into alternative measures or methods of purifying contaminated fish to render them fit for consumption. Toxic effects occur when excretory, metabolic, storage and detoxification mechanisms are no longer able to counter uptake eventually resulting in physiological and histopathological changes. These changes can also be altered by water physicochemistry such as $\mathrm{pH}$, alkalinity, increase total dissolved solid, conductivity salinity etc. and this has general effect on growth and development of fishes. With fish constituting an important link in the food chain, its contamination by toxic metals causes a direct threat, not only to the entire aquatic environment, but also to humans that utilize it as food. From a human health perspective cadmium and lead have been identified as primary contaminants of concern with cumulative effect (Cunningham and Saigo, 1997). Lead is the number one environmental poison amongst the toxic heavy metals all over the world, causing serious health hazards to humans, especially to young children. Over exposure to $\mathrm{Pb}$ causes damage to foetal nervous system, increasing the risk of premature birth or low birth weight. Other effects associated with consumption of foods containing high level $\mathrm{Pb}$ contents include: inhibition of biosynthesis of haem, severe vomiting, intestinal cramps, circulatory disorder, madness and death (Cunningham and Saigo, 1997). Chronic exposure to cadmium is associated with heart disease, anaemia, skeletal weakening, 
depressed immune system response and kidney and liver diseases (Burger et al., 2007). These metals have no bio-importance in human biochemistry and physiology, but its consumption, even at very low concentration can be toxic (Young, 2005). Even for metals with bio-importance such as zinc, nickel and chromium (Abduljaleel and Shuhaimi-Othman, 2011), dietary intake has to be maintained at the regulatory limits, as excesses will result in poisoning or toxicity (Young, 2005). This is because they combine with body biomolecules such as metal-binding protein and enzymes to form stable biotic compounds, thereby mutilating their structures and hindering them from performing the designated functions within the body system (Duruibe et al., 2007). This study was carried out to assess the uptake kinetics of two heavy metals lead and cadmium in African catfish juveniles and their ability to depurate during subsequent exposure to clean water

\section{MATERIALS AND METHOD}

Sample Collection: 140 samples of Clarias gariepinus of average weight $5.3 \mathrm{~g}$ and length $5.8 \mathrm{~cm}$ were purchased from a local culture pond at Nkpolu. Fish were transferred to University of Port Harcourt toxicology laboratory at the Department of Animal and Environmental Biology and kept for 2 weeks for acclimatization under laboratory conditions $25+\underline{1}^{\circ} \mathrm{C}$ with light ventilation and water quality parameters (TDS=8.92 ppm, PH 8.6) Temperature $26.2^{\circ} \mathrm{C}$, salinity $0.01 \mathrm{ppt}$, conductivity 17.80 us. DO $48 \mathrm{mg} / \mathrm{L}$ were measured during the experiment.

Range Finding Test (First Exposure): Rage finding testing of cadmium and lead toxicity were performed using different concentrations of $\mathrm{Pb}$ and $\mathrm{Cd}(100 \mathrm{mg}$, $250 \mathrm{mg}, 500 \mathrm{mg}, 750 \mathrm{mg}$, and $1000 \mathrm{mg} / \mathrm{l}$ both with 2 replicates and each concentration containing 4 fish with (4 fish in each control). The lead salt was insoluble, so it was dissolved using the magnetic stirrer hot plate to obtain a uniform solution. The concentrations of each heavy metals concentration caused $100 \%$ mortality in fish within $12-15$ hours and the second exposure was conducted using lower concentration.

Definitive Testing: Second exposure (Sublethal concentration): The concentrations of metals were reduced to $5,10,15,20$, and $25 \mathrm{mg} / 1$ for both lead and cadmium with 4 fishes in each tank. Aerators were fixed to supply more oxygen to each tank and allow to stand for 5 days after which the samples were taken to the lab for analysis and number of death recorded each day. Only one fish from each duplicate was taken and sacrificed for analysis at initial treatment.
Depuration Period: The remaining fish were placed into clean tanks filled with clean water which allows normal biological activities. The fishes were fed and water was changed continuously to determine rate at which it will take to purge it of its contaminants $(\mathrm{Pb}$ and $\mathrm{Cd}$ ).

Sample Digestion (Biota) and Analysis: The biota (fish)were dried to remove $\mathrm{H}_{2} \mathrm{O}$ content and crushed using the crucible to expose a better surface area to obtain the analytes. $10 \mathrm{ml}$ of digestion mixture (sulphuric, nitric and pechnoric acid) were added in the ratio of 2:2:1 respectively. Samples were heated using the heating mantel until a colour change was obtained. Sample was allowed to cool and then filtered using Whatman's filter paper into a $100 \mathrm{ml}$ standard volumetric flasks. Sample was made up with distilled water to calibration mark and poured in a poly bottle and sent for heavy metal analysis.

Digestion for the water Sample and Analysis: $50 \mathrm{ml}$ of the water sample was measured and digested with $3 \mathrm{ml}$ of nitric acid, it was heated using heating mantle for 15 mins. Filter sample to avoid impurities in to $50 \mathrm{ml}$ standard volumetric flask. Poured sample in a poly bottle and taken to AES (model Agilent technologies 4210 MP-AES) for analysis.

Statistical Analysis: Data obtained were subjected to ttest to determine the difference in the heavy metals concentrations between the two toxicants $\mathrm{Pb}$ and $\mathrm{Cd}$ salt with statistical significant level set at $\mathrm{p}<0.05$ using ASSISTAT Version 7.7 (2017).

\section{RESULTS AND DISCUSSION}

The result obtained after 14 days of acclimation show mortality rate of $<1 \%$ as shown in Table 1 . In 24 hours, percentage death rate was $25,50,25,50 \%$ at 10,15 , 20 and $25 \mathrm{mg} / 1$ respectively for cadmium and 25,25 , $50,50 \%$ at $5,10,15$, and $25 \mathrm{mg} / \mathrm{L}$ for lead respectively. The uptake, depuration, percentage depurated of cadmium and lead after 5 days is shown in the table 2 and figures 2 and 3 . At $5 \mathrm{mg} / \mathrm{L}$ concentration, mean metal uptake of cadmium was $0.055 \pm 0.038$, at $10 \mathrm{mg} / \mathrm{L}=0.057 \pm 0.016,15 \mathrm{mg} / \mathrm{L}=$ $0.058 \pm 0.029,20 \mathrm{mg} / \mathrm{L}=0.018 \pm 0.024$ and $25 \mathrm{mg} / \mathrm{L}$ $=0.12 \pm 0.084$. Mean uptake for lead was 5 $\mathrm{mg} / \mathrm{L}=0.3005 \pm 0.219,10 \mathrm{mg} / \mathrm{L}=0.1935 \pm 0.088,15$ $\mathrm{mg} / \mathrm{L}=0.1895 \pm 0.076,20 \mathrm{mg} / \mathrm{L}=0.2355 \pm 0.201$ and $25 \mathrm{mg} / \mathrm{L}=0.2805 \pm 0.087$. Percentage uptake is represented in table 3 and after depuration period, percentage loss figure 1 . This study was done to assess the potential uptake kinetics of heavy metals (Cadmium and Lead) in the African Catfish. Uptake rate and depuration ability through exposure to different concentration of introduced heavy metals 
were assessed. Both metals displayed characteristic of being toxic by increasing mortality rate at short period of fish exposure (48h) (El-Shenawy. 2004) causing more than $1 \%$ death rate compared to period of 2 weeks of acclimation. Comparison of death rate between both treatment showed lethality in order of $\mathrm{Pb}>\mathrm{Cd}$, this implies that lead was more toxic. Accumulation of metals in fish is dependent on metals concentration and period of exposure (Dublin-Green et al., 1994; Alves et al., 2006). Other factors such as water salinity, $\mathrm{pH}$, hardness and temperature, size age (young fish tend to be more susceptible) ecological need and feeding habit play significant role too, this can explain reason for irregular values in concentration $25 \mathrm{mg} / \mathrm{l}$ of lead and $20 \mathrm{mg} / \mathrm{l}$ of cadmium accumulation is not only determined by concentration and exposure but metals are also preferentially accumulated by different organs of the body (Bilgrami et al., 1996; Rauf et al., 2009). Most metals taken up by organism do not bioaccumulate but instead are processed internally and excreted (Wallace et al., 2003). Chronic toxicity of cadmium is a function of total amount of metal accumulated (Borgmann et al., 2001). Uptake percentage of cadmium $5 \mathrm{mg} / \mathrm{l}$ is $1.9 \mathrm{E}+01,10 \mathrm{mg} / \mathrm{l}=1.0 \mathrm{E}+01,15 \mathrm{mg} / \mathrm{l}=6.0 \mathrm{E}+00,20$ $\mathrm{mg} / \mathrm{l}=1.4 \mathrm{E}+00,25 \mathrm{mg} / \mathrm{l}=8.3+00$. For $5 \mathrm{mg} / \mathrm{l}$ is $2.0 \mathrm{E}+01,10 \mathrm{mg} / \mathrm{l}=1.0 \mathrm{E}+01,15 \mathrm{mg} / \mathrm{l}=8.8 \mathrm{E}+00,20$ $\mathrm{mg} / \mathrm{l}=9.9 \mathrm{E}+00,25 \mathrm{mg} / \mathrm{l}=1.0+01$. Accumulation rate is $\mathrm{Pb}>\mathrm{Cd}$ this implies that lead is preferably taken in by Clarias gariepinus. Bioaccumulation is dependent on structure and function of different tissues (Kotze, 1997). It is also known ingested portion of metals do not accumulate in tissues and are excreted after passing through digestive system (Glover \& Hogstand, 2002). This could explain variation in concentration $25 \mathrm{mg} / 1$ of lead and $25 \mathrm{mg} / 1$ of cadmium with uptake percentage of $8.3 \mathrm{E}+00$ and $1.0 \mathrm{E}+01$ respectively. Percentage is low despite high concentration of lead.

Table 1: Fourteen Days Acclimation Period, 13 of 140 samples died before 14 days of acclimation

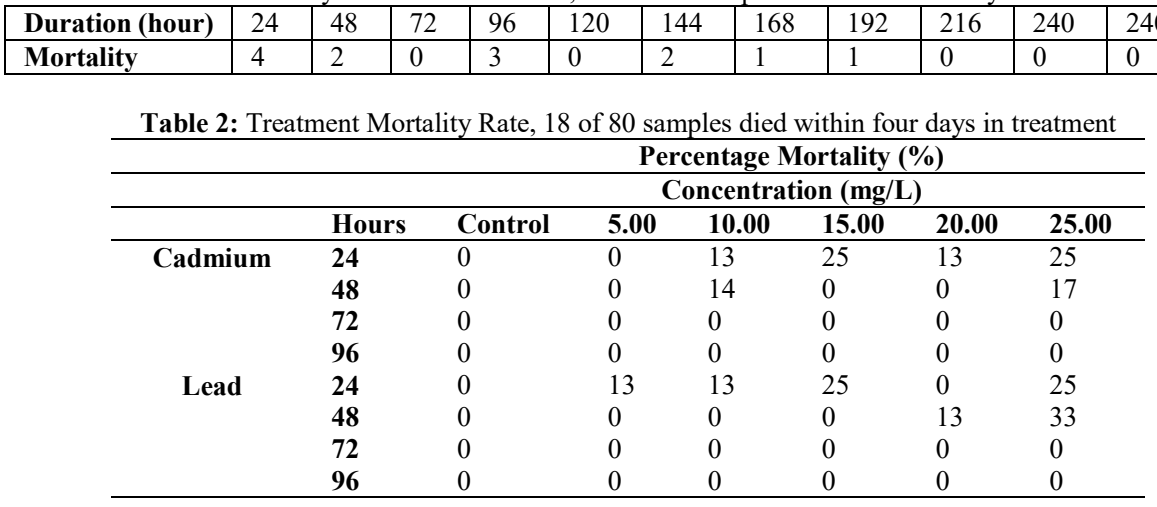

Table 3: The concentration of Cadmium $(\mathrm{Cd})$ and Lead $(\mathrm{Pb})$ in $\mathrm{mg} / \mathrm{kg}$ at Uptake and After Depuration

\begin{tabular}{lllllll}
\hline \multirow{2}{*}{ Conc. } & \multicolumn{2}{l}{ Cadmium (Cd) } & \multicolumn{3}{c}{ Lead (Pb) } \\
\cline { 2 - 7 } & Uptake & After Depuration & $\begin{array}{l}\text { Percentage } \\
\text { Uptake }\end{array}$ & Uptake & After Depuration & $\begin{array}{l}\text { Percentage } \\
\text { Uptake }\end{array}$ \\
\hline $\mathbf{5}$ & $0.055 \pm 0.038^{\mathrm{a}}$ & $0.0335 \pm 0.0007^{\mathrm{a}}$ & 18.68 & $0.3005 \pm 0.219^{\mathrm{a}}$ & $0.0815 \pm 0.0007^{\mathrm{a}}$ & 20.47 \\
$\mathbf{1 0}$ & $0.057 \pm 0.016^{\mathrm{a}}$ & $0.0105 \pm 0.0007^{\mathrm{a}}$ & 10.17 & $0.1935 \pm 0.088^{\mathrm{a}}$ & $0.19355 \pm 0.0007^{\mathrm{a}}$ & 10.17 \\
$\mathbf{1 5}$ & $0.058 \pm 0.029^{\mathrm{a}}$ & $0.00575 \pm 0.0007^{\mathrm{a}}$ & 5.95 & $0.1895 \pm 0.076^{\mathrm{a}}$ & $0.1115 \pm 0.0007^{\mathrm{a}}$ & 8.76 \\
$\mathbf{2 0}$ & $0.018 \pm 0.024^{\mathrm{a}}$ & $0.018 \pm 0.0007^{\mathrm{a}}$ & 1.41 & $0.2355 \pm 0.201^{\mathrm{a}}$ & $0.1465 \pm 0.0007^{\mathrm{a}}$ & 9.92 \\
$\mathbf{2 5}$ & $0.12 \pm 0.084^{\mathrm{a}}$ & $0.0665 \pm 0.0007^{\mathrm{a}}$ & 8.26 & $0.2805 \pm 0.087^{\mathrm{a}}$ & $0.1085 \pm 0.0007^{\mathrm{a}}$ & $10.08 \mathrm{~s}$ \\
\hline
\end{tabular}

${ }^{\mathrm{a}-\mathrm{b}}$ Different letters in the same row indicate significant difference $(\mathrm{P}<0.05)$

Table 4: Summary of Percent lost to water after depuration

\begin{tabular}{|c|c|c|c|c|}
\hline \multirow[t]{2}{*}{ Initial Conc. } & \multicolumn{2}{|c|}{ Cadmium (Cd) } & \multicolumn{2}{|l|}{ Lead (Pb) } \\
\hline & Depurated & Percentage & Depurated & Percentage \\
\hline 5 & 0.0215 & 40.00 & 0.3005 & 73.045 \\
\hline 10 & 0.0465 & 80.70 & 0.1935 & 20.413 \\
\hline 15 & 0.5215 & 90.00 & 0.1895 & 41.425 \\
\hline 20 & 0.05215 & 77.78 & 0.2355 & 37.580 \\
\hline 25 & 0.0535 & 45 & 0.2805 & 61.141 \\
\hline
\end{tabular}

Depuration: Clarias species have shown ability to depurate / eliminate heavy metals but tend to be slow, (El-Shenawy., 2004). This can be attributed to reduction in physiological processes such as reduction in respiratory rate and movement. This is because the organism tend to survive through avoidance mechanism and this reduces rate of elimination of contaminants because increase in ammonia and faecal excretion is associated with an increase in respiration rate (El-Shenawy., 2004). Closure in clam (corbicula flominea) in response to water borne metals was reported in previous work by Chung-Min et al., 
(2004). Uptake percentage was high in lead but cadmium was preferably depurated, depuration is also related to availability of water Okereke et al., (2017) reported that depuration of contaminants on shellfish (Tympanatonus fuscastus) was faster during rainy season than dry season, this means that for effective depuration to occur there is need for availability of source that is water which attained the safety standard. Cadmium was preferably depurated compared to lead due to this could be due to insolubility nature of lead in water under normal condition or affinity for tissues. This indicates that lead take longer period to depurate from the fish tissues, this insoluble nature can interfere with respiratory function of the gills resulting in acute respiratory stress and death by suffocation. The good news is that due to insoluble nature of lead in water, they are most times adsorbed on to sediment and suspended particles hence reducing its availability to marine organisms but the organisms at the bottom is more likely to be exposed.

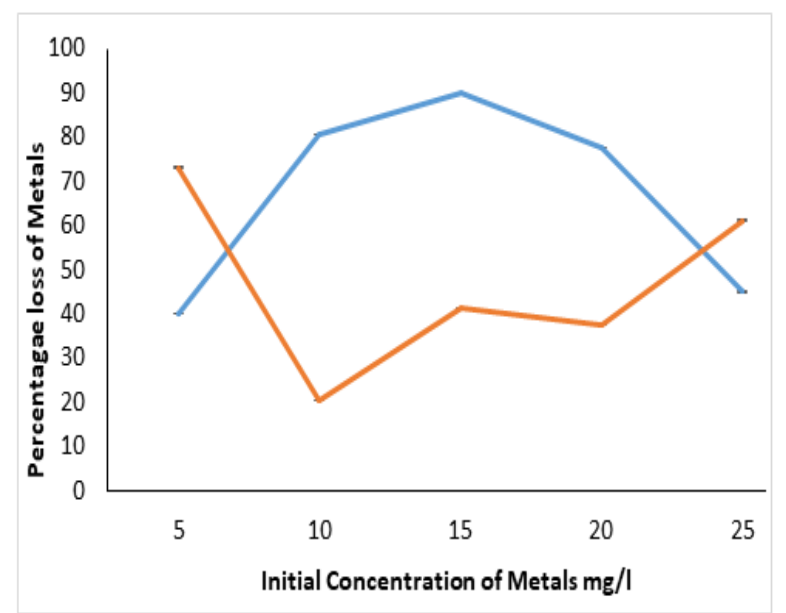

Fig 1: Percentage loss to water of lead and cadmium $n=2$

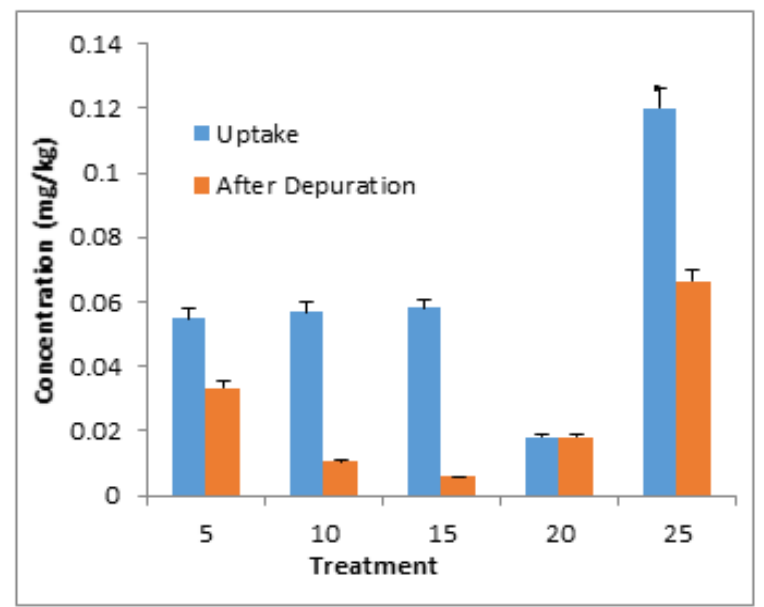

Fig 2. The Concentration of Cadmium at uptake and after depuration. $\mathrm{n}=2$

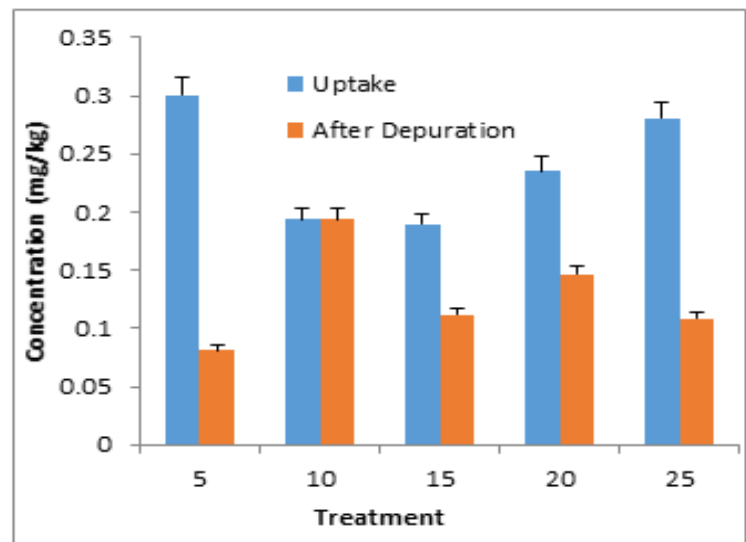

Fig 3: The Concentration of Lead at uptake and after depuration. $\mathrm{N}=2$

Conclusion: This study revealed that Heavy metals can be eliminated from fish by transferring them into clean water before consumption but this process of natural depuration tends to be slow as shown in this research work. Based on these findings catfish have shown to be good accumulators of heavy metals but can be depurated if allowed to swim in clean water. Depuration is not a substitute for pollution control but a process to enhance healthy living by improving safety consumption of sea food. Farmers and consumers should depurate fishes before consumption or storage

\section{REFERENCES}

Abduljaleel, SA; Shuhaimi- Othman, M (2011). Metals Concentrations in Eggs of Domestic Avian and Estimation of Health Risk from Eggs Consumption. J. Bio. Sci., 11: 448-453.

Aksoy, A (2008). Chicory (Cichorium intybus L.): A Possible Biomonitor of Metal Pollution. Pak. J. Bot. 40: 791-797.

Alves, LC; Glover, CN; Wood, CM (2006). Dietary Pb Accumulation in Juvenile Freshwater Rainbow Trout (Oncorhynchus mykiss) Aqua. Toxicol. 78: 217-23.

Bilgrami, KS; Sanjib-Kumar, SS; Kumar, S (1996). Rivers biota as Indicators and Scavengers of Heavy Metal Pollution. National Academy of Science Letters.19 (11-12):205-207.

Borgmann U; Neron R; Norwood, WP (2001). Quantification of bioavailable Nickel in sediments and toxic thresholds to Hyalella azteca. Environ. Pollut. 111(2):189-198. 
Burger, J; Gochfeld, M; Shukla, T; Jeitner, C; Burke, S; Donio, M; Shukla, S; Snigaroff, R; Snigaroff, D; Stamm, T; Volz, C (2007). Heavy metals in Pacific cod (Gadus macrocephalus) from the Aleutians: Location, age, size and risk. J. Toxicol. Environ. Health Part A: 70(22): 1897-1911.

Castro-González, MI; Méndez-Armenta, M (2008). Heavy metals: Implications Associated to Fish Consumption. Environmental Toxicol. \& Pharma. 26: 263-271.

Chung-Min, L; Li-John, J; Bo-Ching C (2005). Riskbased approach to appraise valve closure in the clam Corbicula fluminea in response to waterborne metals. J. of Environ. Pollut. 135 (1): 41-52.

Cunningham, WP; Saigo, BW (1997). Environmental Science: A Global Concern. Wm. C. Brown Publisher, New York, USA: 389.

Dublin-Green, WF; Nwankwo JN; Irechukwu, DO (1994). Effective regulation and management of HSE issues in the petroleum industry in Nigeria. Proceedings of the SPE International Conference of Health, Safety and Environment in Oil and Gas Exploration and Production, Caracas, Venezuela, Jun. 7-10, Paper No. SPE 40/26.

Duruibe, JO; Ogwuegbu, MOC; Egwurugwu, JN (2007). Heavy metal pollution and human biotoxic effects. Inter. J. Phys. Sci. 2(5): 112-118

El-Shenawy, NS (2004), Heavy metal and microbial depuration of the clam Ruditapes decussatus and its effect on bivalve behavior and physiology. Environ. Toxicol. 19: 143-153. doi: $10.1002 /$ tox.20007

Glover, CN; Hogstrand, C. (2002). In vivo characterization of intestinal zinc uptake in freshwater rainbow trout. J. of Experi. Biol. 205:141-150.

Kotze PJ (1997) Aspects of water quality, metal contamination of sediment and fish in the Oilfants River, Mpumalanga. M.Sc. Thesis, Rand African University South Africa.

Okereke, NA; Davies, OA; Ike, JC; Obasi, JC; Ezeonyejiaku CD.(2017)Effect of depuration on heavy metal concentrations in periwinkle (Tympanatonus fuscastus) from a polluted creek in Rivers State, Nigeria. J Aqua Sci. 32 (1): 193 203
Rauf, A; Javed, M; Ubaidulalh, M (2009). Heavy metal levels in three major carps (Catla catla, Labeo Rohita and Cirrhinam rigala) from the river Ravi, Pakistan. Pakistan Veterinary Journal 29(1): 24-26 Available from: https://www.researchgate.net/publication/316921 902_[accessed Sep 17 2019].

Singh, RK; Chavan, SL; Sapkale, PH (2007). Heavy metal concentrations in water, sediments and body tissues of red worm (Tubifex spp.) collected from natural habitats in Mumbai, India. Environ. Monit. Assess. 129: 471-481.

Sprocati, AR; Alisi, C; Segre, L; Tasso, F; Galletti, $\mathrm{M}$; Cremisini C (2006) Investigating heavy metal resistance, bioaccumulation and metabolic profile of a metallophile microbial consortium native to an abandoned mine. Sci. of the Total Environ. 366: 649-658 Available from: https://www.researchgate.net/publication/722371 9_ [accessed Sep 17 2019]

UNEP (2008), Interim review of scientific information on lead, taken 2008-05-18 from http://www.chem.unep.ch/Pb_and_Cd/SR/Files/2 008/UNEP_Lead_review_Interim-mar1028.

UNEP, (2008). Interim review of scientific information on cadmium, taken 2008-05-18 from http://www.chem.unep.ch/Pb and_Cd/SR/Interi $m$ reviews.html.

Wallace WG; Lee, BG; Luoma SN (2003) Subcellular Compartmentalization of $\mathrm{Cd}$ and $\mathrm{Zn}$ in two bivalves. Significance of Metal-Sensitive Fractions (MSF) and Biologically Detoxified metal (BDM). Marine Ecology Progress Series 249, 183-197. doi:10.3354/meps 249183

Young, RA (2005). Toxicity Profiles: Toxicity Summary for Cadmium, Risk Assessment Information System. University of Tennessee, Nashville, TN, USA. 